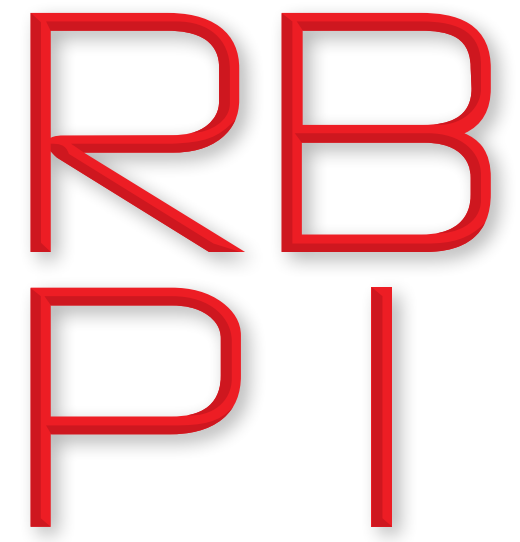

Revista Brasileira de Política Internacional ISSN 1983-3121

http://www.scielo.br/rbpi

\section{Ana Paula Tostes ${ }^{1}$}

1Universidade do Estado do Rio de Janeiro, Relações Internacionais, Rio de Janeiro, RJ, Brazil (aptostes@uerj.br)

iD ORCID ID:

orcid.org/0000-0002-9642-6211

\section{Yasmin Renni' ${ }^{2}$}

2Universidade Nova de Lisboa, Faculdade de Ciências Sociais e Humanas, Lisboa, Portugal (a59506@campus.fcsh.unl.pt)

iD ORCID ID: orcid.org/0000-0001-9799-5902

\title{
Europeanisation to the Eastern borders: Moldova's EU Rapprochement
}

DOI: http://dx.doi.org/10.1590/0034-7329202100210

Rev. Bras. Polít. Int., 64(2): e010, 2021

\section{Abstract}

The geopolitical condition in Eastern Europe brings about a new dynamic of governance. The neighbourhood matters for the EU, even more so after the 2000's enlargements. This paper analyses the Europeanisation dynamics in the Republic of Moldova as a case for a critical view of the EU's modern external governance to the Eastern borders.

Keywords: European Union; European Neighbourhood Policy; EU Eastern Partnership; Republic of Moldova; Europeanisation.

Received: May 29, 2021

Accepted: September 15, 2021

\section{Introduction}

\section{Copyright:}

- This is an open-access article distributed under the terms of a Creative Commons Attribution License, which permits unrestricted use, distribution, and reproduction in any medium, provided that the original author and source are credited.

- Este é um artigo publicado em acesso aberto e distribuído sob os termos da Licença de Atribuição Creative Commons, que permite uso irrestrito, distribuição e reprodução em qualquer meio, desde que $o$ autor e a fonte originais sejam creditados.

${ }^{1}$ There is a clear division between pro-Russia and pro-EU attitudes among the politicians and political parties in Moldova. Surveys have measured how much foreign leaders can influence national politics and Moldova is a country strongly influenced by Putin's image. See Gallup International (2018). 
Russia has traditionally used Transnistria as a tool to maintain geopolitical influence and military presence in Moldova ${ }^{2}$, however, the country has never officially proposed a serious neighbourhood project for cooperation toward western members of the Commonwealth of Independent States (Devyatkov 2021, 55).

Despite the limits of EU enlargement, and the lack of membership projections for several third countries, the EU governance model has revolutionised traditional forms of regional integration by promoting a set of rules that regulate the life of national and international society, whether in a regional or global multilateralism. New dynamics of governance can be interpreted as several efforts to generate actions and promote European values of democracy, Western liberal values, rule of law, development, and democratic institutions. In this context, this paper considers the European Neighbourhood Policy (ENP), a programme for EU's South and Eastern neighbours to foster development, political stability, and democracy. Particularly, the Eastern Partnership (EaP) appeared as a pragmatic foreign policy orientation for a region in geopolitical struggle between European and Russian influence.

The ENP presents a vision of a ring of countries sharing the EU's fundamental values and objectives, drawn into an increasingly close relationship, surpassing co-operation to involve a significant measure of economic and political integration (Popescu 2005). To its advantage, this is both feasible and necessary. Greater market integration under the ENP and enhanced political dialogue with the EU were seen by Eastern neighbours as a positive alternative for partnerships and cooperation.

The inspiration for the ENP was pragmatic, seeking to protect the interests of the EU and its Member-States. But it also claimed to be based on "shared values". In fact, shared values were an aspiration rather than a reality in most partner countries. The gap between aspiration and reality proved to be one of the ENP's main deficiencies (Gstöhl \& Lannon 2014, 206-207).

The EU's cooperation and financial support towards its Eastern neighbours comes with strings attached, what Lavenex and Schimmelfennig (2011) call "the EU's external governance". This is because the partnership includes the integration of pieces of the acquis communautaire into EaP countries, a selective extension of some EU rules, norms and policies into local legislation, harmonising standards and strengthening the political dialogue (Parmentier 2017). Gawrich et al. (2009) describe and designate the phenomenon as Europeanisation ${ }^{3}$. Exadaktylos (2017) highlights how multidisciplinary the study of the ENP is, being Europeanisation on of the multiple possible lenses to assess it - which will be used in this article.

\footnotetext{
${ }^{2}$ Transnistria is a narrow strip of land separated from the main part of Moldova by the river Nistru, with a small population of some 400,000 people (compared to Moldova's 3.4 million people).

${ }^{3}$ See Barbé et al. (2009) for a comparison on different approaches.
} 
In line with Radaelli's (2000) explanation on the different senses the concept of Europeanisation can be applied to, it is important to highlight that this article considers the main understanding of the specialised literature on Europeanisation as the phenomenon of the EU influencing and exporting its values, ideas and norms to other states and social and political spheres, by sharing and diffusing its routines, policies, and institutions. ${ }^{4}$ Yet, Börzel (2002) and McCauley (2011) highlight the EU is also influenced and affected by the states and societies of the region, forming thus the top-down and bottom-up dynamics of Europeanisation ${ }^{5}$. In this article we do not consider the bottom-up dynamic, as EaP countries are not EU-members. Although the article aims to contribute with an analysis about the levels of perception, it is so as a source of reflection and arguments on effectiveness, compliance and legitimation of the EU influence on Moldova.

The 2004 enlargement was a turning point to a geopolitical target in the EU, when many of the recent democratic Eastern European countries from the former Soviet Union joined the integrated region ${ }^{6}$. However, not only EU members are lured into the Europeanisation process. There is also a process of influencing countries at the borders of the EU. This external influence has been shaped by a specific policy for third countries: the ENP. According to Lavenex and Schimmelfennig (2011), this is a model for functional cooperation between governments as a means to promote democracy and diffuse its values and ideas. Important to note that within the ENP, membership was not on the table - it was neither promised nor excluded as Parmentier (2017) highlights.

Gawrich et al. $(2009,5)$ propose three dimensions of Europeanisation research when reviewing the early 1990s' literature: i) Membership Europeanisation, referring to the impact of the EU on its (current) member-states; ii) Enlargement Europeanisation, related to countries in the accession process and candidate countries (perspective members); and iii) Neighbourhood Europeanisation, for those without membership perspective, also considered "EU's neighbouring 'outsiders". On Spruds' (2016) perspective, Europeanisation dynamics can be identified as a modernisation mirror for former Soviet countries.

In addition, geopolitics is a key factor in European motivations and the pursuit of further expansion of its foreign policies in the face of its biggest competitor of influence in the region: Russia. Situated between Russia and the EU, the EaP countries can be considered a strategic foreign policy goal for the EU's regional strategy and borders. However, bilateral relations towards these countries have evolved at different paces, according to their domestic economic and institutional structures. Differentiation and flexibility can be identified as two constants in the ENP (Korosteleva et al. 2020). In this scenario, this article aims to focus on the Neighbourhood

\footnotetext{
${ }^{4}$ Regarding the debates on the concept of Europeanisation, see for example Börzel and Risse (2000; 2003); Featherstone and Kazamias (2001); Featherstone and Radaelli (2003); and Dyson (1999).

${ }^{5}$ Shortly, the top-down Europeanisation process has been understood mostly by the impact and influence of EU ideas, policies, institutions, norms, etc. towards the member-states, or even sub-national agencies and actors.

${ }^{6}$ It was from 2004 that the EU started to incorporate former Soviet countries as member-states.
} 
Europeanisation and, more specifically, will analyse concepts, theoretical constructions, and data for the Republic of Moldova. The assessment on Moldova is part of a broader research agenda which intends to contribute to the elaboration of a model of analysis for the Europeanisation of all six EaP countries: Moldova, Armenia, Azerbaijan, Belarus, Georgia, and Ukraine.

We consider the ENP and the agreements within its framework as a top-down Europeanisation process. The ENP is a EU foreign relations instrument for developing countries, including those in the neighbourhood willing to be closer to the EU. The ENP follows a blueprint for enlargement, as a response to the European Security Strategy (ESS). Under the ENP, the EU offered its neighbours strengthened political partnership (Popescu 2011,35). The EU aimed to create a "ring of well governed, stable, democratic and prosperous states in the neighbourhood, while avoiding talks over EU accession for countries like Ukraine or Moldova” (Popescu 2011 apud Batt et al. 2003; Emerson et al. 2018; Kelley 2004b). Since the new policy was launched, the privileged neighbours started to create mutual commitments to build common values and actions for reaching good governance, rule of law and the promotion of economic and democratic principles.

The ENP process is supported by an Action Plan (AP) prepared for neighbouring countries that are not in the EU's enlargement agenda. The APs introduced specific goals in different countries in order to implement ENP's policies. The APs would draw on a common set of principles and bilateral relations to contribute for regional and sub-regional cooperation to reinforce efforts to meet the objectives of the ESS. In this sense, different impacts of Europeanisation can be found in the neighbours. Thus, we must consider each country individually to assess some measures of success of this initiative, particularly in light of the 10 years of the EaP (2009-2019 timeframe).

The EU contributes with financial assistance to ENP countries so as to promote reforms and adjustments, influence policies, institutions, laws (political, economic, institutional, etc.) and enhance their local and national transformation towards a democratic model in line with the EU's. ENP's policies prioritise sectors considered key areas for stability: Democracy Promotion, Justice and Home Affairs, and Economic Cooperation and Trade. Thus, the adoption of EU-aligned regulations and norms and the institutional adaptation to accomplish ENP policies can be observed as a measure of a top-down Europeanisation.

In order to assess the effectiveness of the implementation of EU policies and reforms that can be considered a Western rapprochement in the same context, public opinion surveys are examined. Surveys on public opinion reveal when citizens perceive the good functioning of policies and EU institutions and standards, usually without the use of coercion mechanisms in the European daily life. In other words, positive perceptions on the EU empower its institutions to expand the reach of its norms, increase effectiveness and the impacts on society. That is because the less a rule requires strength and coercion mechanisms to be obeyed, the more effective it is. Such effectiveness, however, depends on the extent to which this standard is recognised by the society that must respect it as legitimate. In other words, compliance matters in the EU.

According to Gawrich et al. (2009), the lack of an ascension perspective potentially limits the EU's leverage and effectiveness in exerting influence and promoting values and changes; 
still, this article's hypothesis is that the EaP has promoted Europeanisation on the EU's Eastern neighbourhood after a decade of existence.

It is relevant to mention that the decade of the implementation of the EaP and our timeframe (2009-2019) was marked by a pro-Russia President, Igor Dodon, who casted aside the partnership in the period of 2016-2020. This research seeks to identify whether, despite the disinterest of the main domestic political leadership in Moldova for over a third of our timeframe, the European foreign policy that promotes the export of its social, institutional, and political dynamics was able to produce effects of Europeanisation in Moldova. The article presents results restricted to the preliminary effort of creating a model of analysis and identifying a series of variables that can serve for a broader assessment in time and expansion to other countries that fall within the EaP. The analysis of Moldova's case, despite its peculiarities, brings a model that can be reproduced to understand the cases of other countries, associated with their own particularities and contexts.

\section{Sketching a model of analysis}

Exadaktylos and Radaelli (2009) contribute to the debate on research design and causal analysis in European integration by considering the Europeanisation as a sub-field to be acknowledged. Once the EU exists, there is a new political, economic, legal, and social phenomenon to be explored not only regarding its member-states, but also in the neighbourhood outside of its borders. Europeanisation or not, the EU's existence has an impact on the neighbouring outsiders.

The EU has enlarged over time, and its member-states have been experiencing changes along the European integration over the seven decades of existence. The EU has introduced an innovative legal system, one-of-a-kind institutions, norms and laws, a new monetary system, and a new citizenship. It is thus inevitable to question the consequences and impact of the EU. In the literature on European Studies there is a vast debate on the impact of these innovations on the member-states' societies and domestic politics. From this new political perspective, the designation of this phenomenon of impact, influence and export of normative models and legal and institutional adaptations, emerges the concept of Europeanisation - one of little consensus in the literature. As previously explained, we do not consider in this article national and subnational actors, political elites, civil society groups, policies, ideas, and structures influencing EU politics, policies, ideas, and structures, but the public perception in Moldova about EU influence. This can be interpreted as a sign of potential effectiveness of Europeanisation, once people accept the EU's influence on Moldova.

Gawrich et al. (2009) consider three distinct phases and dimensions of Europeanisation research, where each new dimension draws on and adds to the previous one (Gawrich et al. 2009, 5): Membership Europeanisation (the impact of the EU on member-states); Enlargement Europeanisation (the impact of the EU on countries with a clear EU-membership perspective); 
Neighbourhood Europeanisation (the impact of the EU on "outsiders", countries with no immediate accession perspective).

In order to assess Neighbourhood Europeanisation in Moldova, this article firstly draws upon the ENP's Association Agreement (AA) and implementation reports to trace the advances made in promoting change in Moldova by EU initiatives. More specifically, this article will analyse five reports representative of the relationship between the EU and Moldova under construction: "European Neighbourhood Policy in the Republic of Moldova Progress in 2014 and recommendations for actions"; the "Progress Report on the Implementation of the Republic of Moldova-EU Association Agenda" and the "Association Implementation Report", covering the 2014-2019 period. We will look at regulation and law changes (approved and adopted laws) outlined in the reports, as well as cooperation actions as evidence of Moldova's alignment with EU norms and strategies. This can be assessed as an indicator of top-down Europeanisation, as the EU uses the prospect of further cooperation and strengthening of economic relations to promote harmonisation with EU norms and regulation.

Gawrich et al. (2009) categorise Europeanisation associated to the ENP countries in three political dimensions. Firstly, Democracy Promotion comprises the agenda items related to rule of law, civil society, human rights, and fundamental freedom. Secondly, Justice and Home Affairs involves very sovereignty-sensitive policy areas and border policies, mostly orientated for judicial and police cooperation in international and transnational crimes, foreign and security policy and justice depending on cooperation, issues on migration and other demands related to the acceptance of democratic values and freedom. This is even more recurrent in areas where the EU cannot offer concrete rewards for compliance, such as independent judiciary (Knelangen 2007).

Finally, Economic Cooperation and Trade regards topics like employment, consumer protection, taxation, sectorial items, public health, research and innovation, technical regulations, standards, intellectual property rights and competition.

Departing from Gawrich et al.'s (2009) three dimensions, we look at the variations in the World Bank's Worldwide Governance Indicators (WGI). The WGI compile and summarise information from over 30 individual data sources produced by a variety of survey institutes, think tanks, non-governmental and international organisations, and private sector firms with data from industrial and developing countries, including Moldova. ${ }^{7}$ Drawing from multiple reliable sources, the WGI work as a proxy of policy improvements related to governance in the three dimensions of the ENP's policies at a macro level. ${ }^{8}$ The aggregate indicators combine sources in six dimensions of governance described as follows:

\footnotetext{
${ }^{7}$ More information on the sources: https://info.worldbank.org/governance/wgi/Home/Documents\#docReading

8 The WGI project reports aggregate and individual governance indicators for over 200 countries over the period 1996-2019, for six dimensions of governance. However, it is relevant to note there are other indexes to assess similar analyses, such as the EaP index. The choice of the WGI was based on this research timeframe and the level of analysis aimed.
} 
- Voice and Accountability: combines data sources to capture the extent to which a country's citizens are able to participate in selecting their government, as well as freedom of expression, freedom of association, and a free media.

- Political Stability and Absence of Violence: assesses the likelihood of political instability and/or politically motivated violence, including terrorism.

- Governance Effectiveness: reflects the quality of public services and the civil service, and the degree of its independence from political pressures, the quality of policy formulation and implementation, and the credibility of the government's commitment to such policies.

- Regulatory Quality: assesses the ability of the government to formulate and implement sound policies and regulations that allow and promote private sector development.

- Rule of Law: captures the extent to which agents have confidence in and abide by the rules of society, and in particular the quality of contract enforcement, property rights, the police, and the courts, as well as the likelihood of crime and violence.

- Control of Corruption: assesses the extent to which public power is exercised for private gain, including both petty and grand forms of corruption, as well as the "capture" of the state by elites and private interests.

WGI estimates range from -2.5 , which represents a weak governance performance in the analysed category, to +2.5 . WGI's six dimensions relate to Gawrich et al. 's (2009) three dimensions and can be grouped within it.

These analyses will assess indicatives of top-down Europeanisation. However, by analysing public opinion data from EU NEIGHBOURS east project's annual report on Moldova, a perspective on public perception helps to evaluate certain level of acceptance of EU values in Moldova and can be drawn upon from the population's perception and information on the EU.

Since the EU is a result of regional integration, it is not built on mechanisms and strategies of popular participation that characterise democratic processes. It is in fact a model of cooperation between states that was initially supported by intergovernmental agreements according to rules of public international law. Considering the EU has achieved an unparalleled social and political integration by becoming a polity (Hix 2005), it is expected that it will correct its democratic deficit, even ex-post. Not only because of the importance of the Union's legitimation, but also because democratic recognition implies the ability of its rules and policies to impact social behaviour. We start from the assumption that if public opinion data is positive regarding the EU, its policies, standards, regulations, and institutions are strengthened - the EU becomes thus more effective. In other words, perception data that reveals a good assessment of the EU's role, a positive view of being part of the EU, a representative capacity of its institutions, or if there is a perception of confidence or support towards EU institutions, reveal an ability to make policies more effective. 
Institutions and norms work best when they are best evaluated, perceived as representative, fair, and legitimate. The positive perception signals that the EU is empowered and, therefore, greater compliance with its rules and policies are expected. Compliance has a fundamental role in preventing the application of sanctions resulting from non-compliance with the norms and policies. An important concept here is the effectiveness of the norms. According to jurists such as Bobbio (2012), a norm is more effective the less it needs to use its coercion and force mechanisms to be applied. Thus, prevention and compliance are the best mechanisms for recognising the effectiveness of EU standards.

The selected responses from public opinion reports assess the population's recent opinion on the EU and the values associated to it, but they also reflect the heterogeneity within Moldova - which is corroborated by census data. This article intends to contribute to the development of a model of analysis for assessing top-down Europeanisation, first for the case of Moldova with insights on the impact of EU norms, values and institutions on the society. Once the model is developed and tested for Moldova, it may be applied to the other EaP countries. EU relations with its Eastern neighbours have been intensifying since the EaP launch, and on its $10^{\text {th }}$ anniversary the policy was reviewed to adjust to the new scenario ahead, making it relevant to look deeper at what has happened so far.

\section{Results: Assessing evidence of Neighbourhood Europeanisation in Moldova}

The spreading of EU's values, norms, institutions, policies, and ideas might take place in several different ways. As Montesano et al. (2016) put it, within the framework of the ENP, Europeanisation regards the ability of the EU to make use of its 'normative' clout as a mean to foster stability and development in target countries of interest. Thus, some failures and successes may be identified from a comparative perspective.

Both the EU's concern to create a surrounding neighbourhood of democratic countries to the east and south of its borders and the geopolitical condition of Moldova, located between EU and Russia, drove the increase of EU interest in the country. According to Montesano et al. (2016) the inclusion of Moldova in the ENP in 2003 and the EU-Moldova AP from 2005 are evidence to that. These initiatives were further developed with the EaP policies from 2009, coming to the signature of an AA and a Deep and Comprehensive Free Trade Area (DCFTA) 9

From 2009 to 2019 the relationship between the EU and Moldova has deepened and widened in scope, although the past couple of years represented a standstill in their relations due to a period of a pro-Russian President: Igor Dodon (2016-2020). Dodon was the leader of the Electoral Bloc of Communists and Socialists (BECS) representing a Eurosceptic political orientation. New areas of cooperation, a larger alignment in democracy promotion, regulatory approximation, and

\footnotetext{
${ }^{9}$ From the EaP countries, only Moldova, Georgia and Ukraine have such agreements with the EU.
} 
trade and investment initiatives summarised in certain events can be considered milestones of this intensification: the start of the Autonomous Trade Preferences (2009); the start of EU/UNDP Confidence-Building Measures programme (2009); the AA/ DCFTA negotiations (started in 2010); Moldova joining the Energy Community (2010); the beginning of the EU-Moldova Visa Liberalization Dialogue (2010); the entry into force of the visa-free regime for short stays (2014); the conclusion of AA/DCFTA and provisional application (2014); the replacement of the ENP AP by the Association Agenda (2014); the suspension of EU budget support after bank fraud(2015), and the AA fully into force (2016).

The EU-Moldova relationship has already surpassed simple cooperation, including economic integration and deeper political cooperation. Evidence of that is the AA signed in 2014 and encompassing the AA/DCFTA, which according to the EU represents a qualitative step forward in EU-Moldova relations (European Union External Action 2015). As the signature and entry into force of the AA implied the establishment of an institutional framework and required mechanisms for its implementation, the Association Agenda replaced the ENP AP as the guideline to the EU-Moldova relationship. The spread of the EU model in a top-down orientation can be identified by the exportation of EU policies, institutions, norms, and values towards Moldova.

\section{Top-down impacts of Europeanisation in Moldova}

The Association Agenda foresees a number of domestic adjustments to EU directives and standards. Wolczuk (2018) highlights that the key instrument in achieving the AA's set goals of political association and economic integration with the EU is legal approximation. As Parmentier (2017) notes, a DCFTA is more about extensive legal approximation of norms, laws and regulations on trade-related sectors than about adjusting custom tariffs and quotas. For the partner country this means taking on extensive, binding commitments to align its laws and institutions with the acquis $^{10}$ to stimulate political and economic development and institutional modernisation.

Table 1. Approved and adopted laws and regulations under the three dimensions, Moldova

\begin{tabular}{llccc}
\hline & DEMOCRACY & $\begin{array}{c}\text { JUSTICE } \\
\text { AND HOME } \\
\text { PROMOTION }\end{array}$ & $\begin{array}{c}\text { ECONOMIC } \\
\text { COOPERATION } \\
\text { AND TRADE } \\
\text { RELATED }\end{array}$ \\
\hline $\begin{array}{l}\text { Implementation of the } \\
\begin{array}{l}\text { ENP in the Republic of } \\
\text { Moldova Progress (2014) and } \\
\text { recommendations for actions }\end{array}\end{array}$ & $\begin{array}{l}\text { Laws and amendments } \\
\text { to laws: }\end{array}$ & 7 & 4 & 30 \\
\hline
\end{tabular}

Continue

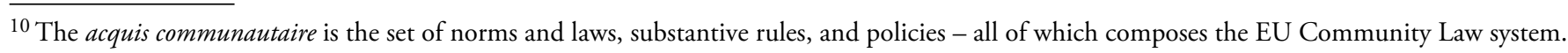


Continuation

\begin{tabular}{|c|c|c|c|c|}
\hline \multirow{3}{*}{$\begin{array}{l}\text { Progress Report on the } \\
\text { Implementation of the } \\
\text { Republic of Moldova- } \\
\text { EU Association Agenda } \\
\text { (Sep. 2014-Mar. 2016) }\end{array}$} & $\begin{array}{l}\text { Laws and amendments } \\
\text { to laws: }\end{array}$ & 10 & 3 & 50 \\
\hline & Regulations: & 8 & 2 & 29 \\
\hline & Cooperation efforts: & 4 & 21 & 19 \\
\hline \multirow{3}{*}{$\begin{array}{l}\text { Association Implementation } \\
\text { Report on Moldova } 2016\end{array}$} & $\begin{array}{l}\text { Laws and amendments } \\
\text { to laws: }\end{array}$ & 4 & 3 & 13 \\
\hline & Regulations: & - & - & 1 \\
\hline & Cooperation efforts: & 1 & 2 & 4 \\
\hline \multirow{3}{*}{$\begin{array}{l}\text { Association Implementation } \\
\text { Report on Moldova } 2017\end{array}$} & $\begin{array}{l}\text { Laws and amendments } \\
\text { to laws: }\end{array}$ & 6 & 3 & 17 \\
\hline & Regulations: & 1 & - & 5 \\
\hline & Cooperation efforts: & 1 & 5 & 6 \\
\hline \multirow{3}{*}{$\begin{array}{l}\text { Association Implementation } \\
\text { Report on Moldova } \\
\text { 2018-2019 }\end{array}$} & $\begin{array}{l}\text { Laws and amendments } \\
\text { to laws: }\end{array}$ & 7 & 10 & 47 \\
\hline & Regulations: & 2 & 1 & 10 \\
\hline & Cooperation: & 2 & 5 & 10 \\
\hline
\end{tabular}

Source: Elaborated by the authors based on data from the Implementation of the ENP in the Republic of Moldova Progress in 2014 and recommendations for actions; Progress Report on the Implementation of the Republic of Moldova - European Union Association Agenda and the Association Implementation Reports on Moldova (2016, 2017 and 2019).

The analysis of the implementation reports indicates the changes promoted by Moldova's Government to harmonise and approximate its domestic norms with the EU's, as well as the improvement in cooperation. ${ }^{11}$ By looking at the regulations, laws and amendments to laws taking place in the 2014-2019 period, it was possible to identify changes in the three elected dimensions, as seen in Table 1. As expected, the pressure to comply with the Association Agenda for the implementation of the AA and the DCFTA certainly speeded up Moldova's normative alignment with the EU. In fact, most of the laws and regulations adopted regard the economic cooperation and trade dimension. This dimension involves a lot of sectorial improvements, as well as harmonisation of standards necessary for accessing the EU's internal market. An important part of the DCFTA is aligning Moldovan trade-related laws to selected EU legislative acts (European Commission 2019). However, when it comes to changes related to democracy promotion, independence of the judiciary and fighting corruption changes proved more complex, taking place at distinct paces.

\footnotetext{
11 When assessing the reports, we considered as cooperation examples the implementation of dialogue and working groups, trainings with external support or upon external orientation, valuation visits from the EU, access to information from the European sphere (e.g., database access) and actions defined as improvement in the bilateral or multilateral cooperation of Moldova and the EU and its member-states.
} 
Figure 1. Regulatory Quality

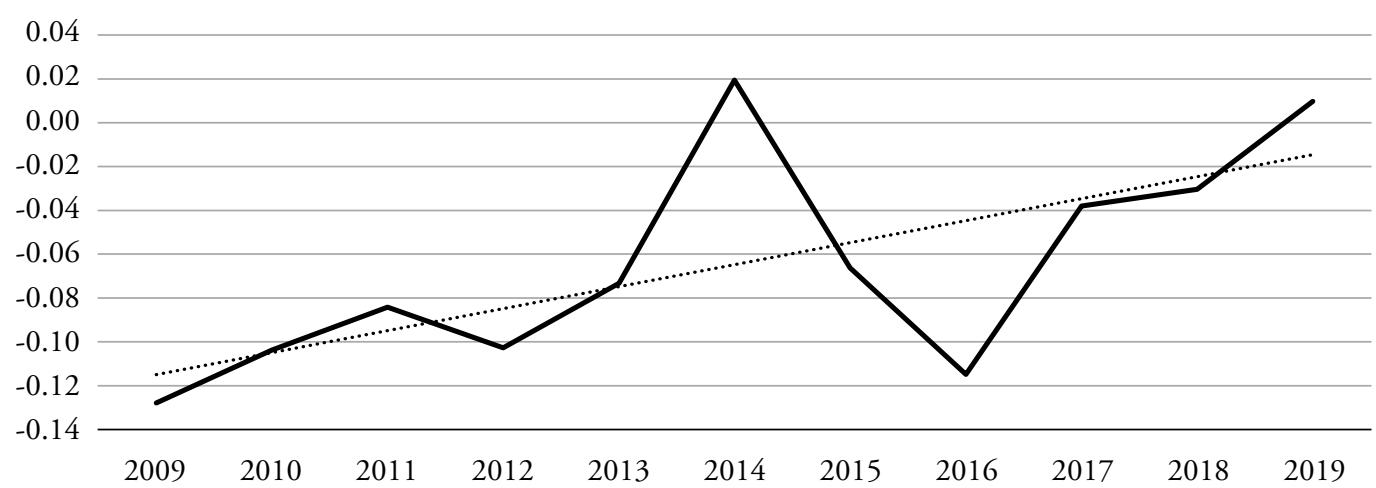

Source: World Bank, WGI.

By looking at the governance indicators for Moldova, it is possible to note the country's sensitive condition. Figures 1 to 6 present the estimates from the six WGI indicators in graphics for the 2009-2019 period, so one can picture the impact of the EaP over a decade. A trend line (dotted line) was added in order to better illustrate the direction of the changes. Of the six WIG indicators, half show a positive trend. The Regulatory Quality indicator evidences the push on normative and regulatory approximation with the EU needed for the AA and the DCFTA.

Figure 2. Voice and Accountability

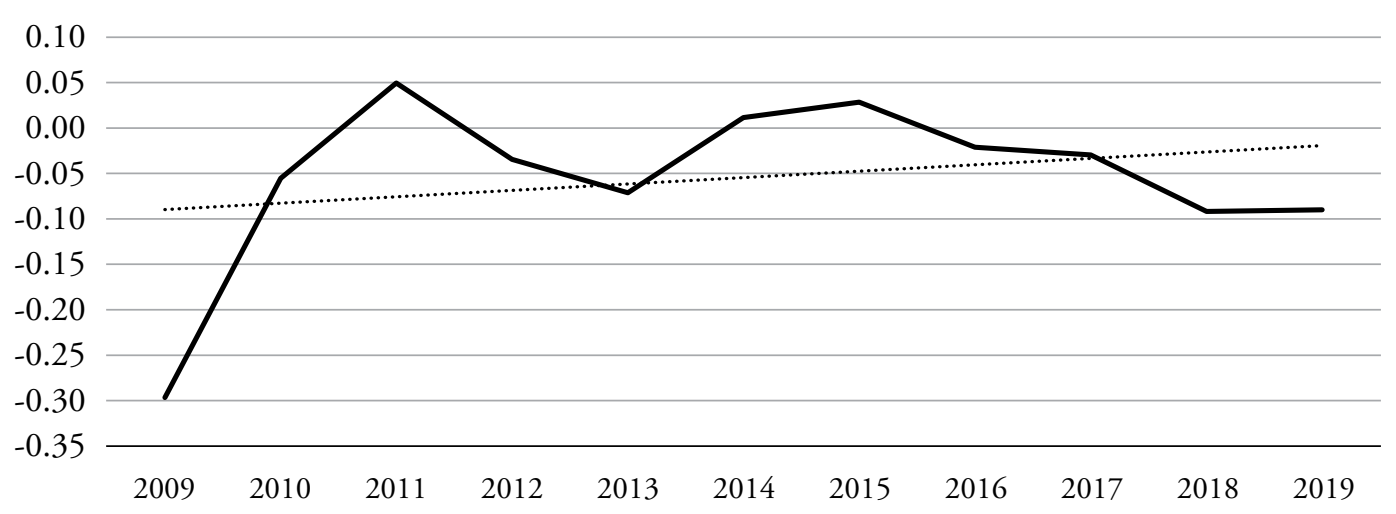

Source: World Bank, WGI.

When comparing the indicator's estimate on Voice and Accountability in 2009 and in 2019, one can note a significant improvement, from -0.30 to -0.9 (Figure 2). Although the indicator shows a positive trend for the analysed period, zooming in on the final years it is possible to note a reversed trend. A similar effect of deterioration can also be observed in the Political Stability and No Violence indicator (Figure 3). This coincides with Dodon's government (2016-2020), the standstill in a number of action plans and cooperation initiatives under the EaP and the internal political crisis Moldova has been facing. 
Figure 3. Political Stability and No Violence

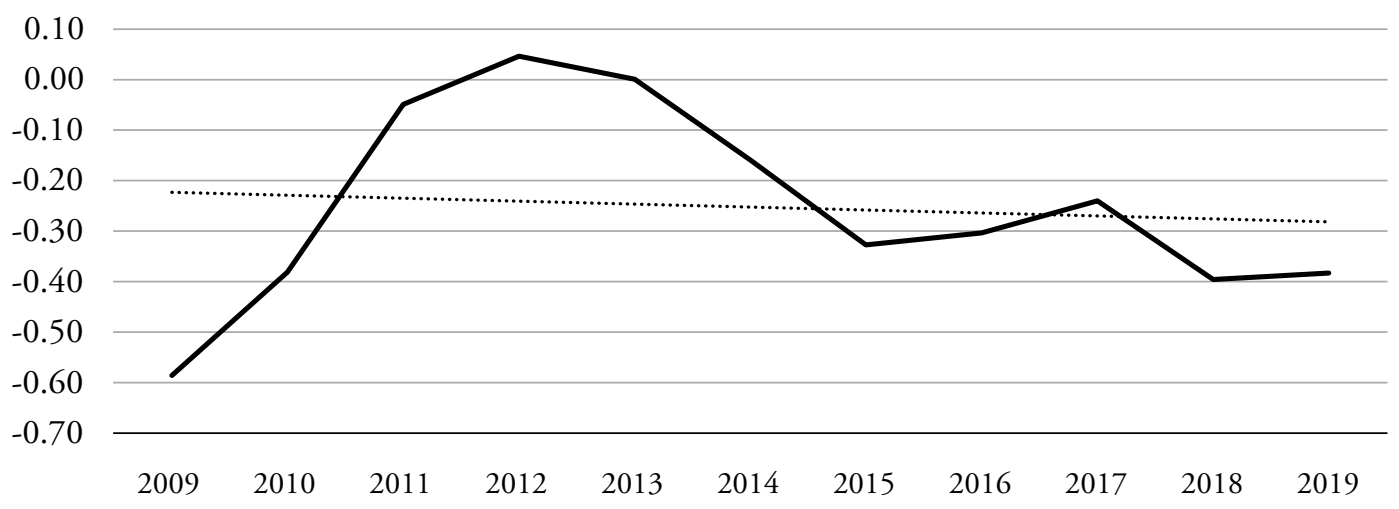

Source: World Bank, WGI.

The Government Effectiveness indicator presents a positive trend for the analysed period, with a significant break in 2015. Nevertheless, a direct causality cannot be established without a deep analysis of the events in 2015, the banking fraud that became public in November 2014, representing 15\% of GDP. A response of the Moldovan authorities, parliament members, prosecutors and judges resulted in trials against those responsible; reform of the judiciary shed light on their autonomy in playing their roles in the Public Administration. Reforms to combat corruption and transform the judiciary were long demanded in the country (Mukherjee 2018). A proactive approach by the government and regulatory authorities took place promptly, with the establishment of a Shareholder Transparency Unit by Moldova's National Bank with supervisory responsibilities in line with the new Bank Recovery and Resolution Law (No.232, 03/Oct/2016) (OECD 2019).

Figure 4. Government Effectiveness

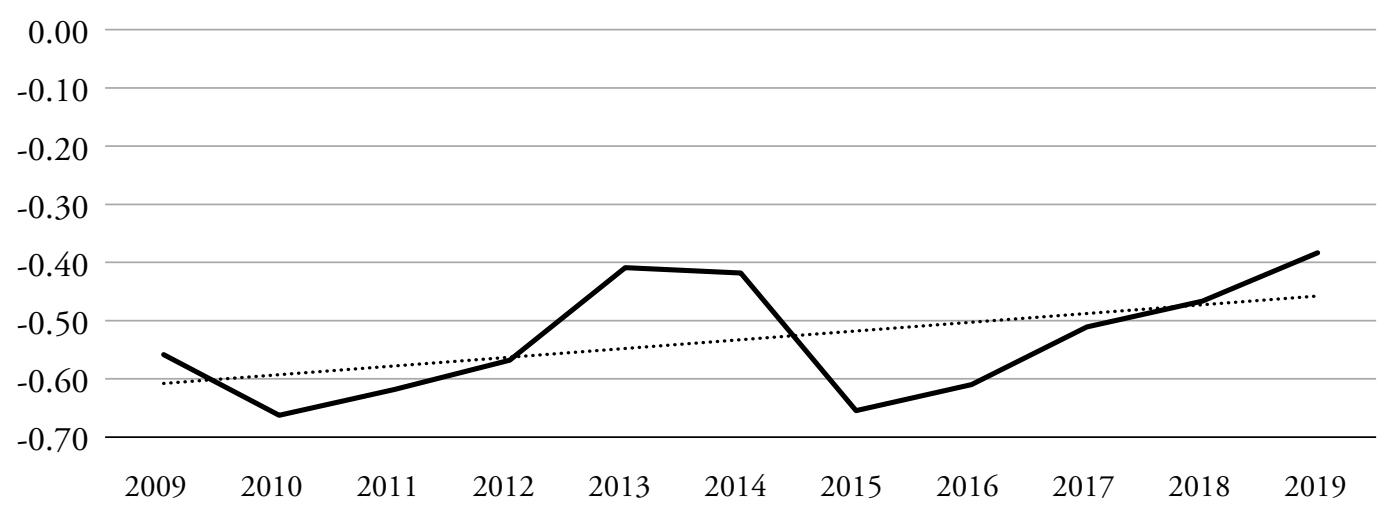

Source: World Bank, WGI.

Research indicates control of corruption is a problem Moldova has not yet managed to efficiently tackle, reflected in this indicator's evolution over time. The results are compatible with other sources and measurements of corruption. We understand fighting corruption is a process which is highly interconnected with most of the other governance areas. 
Figure 5. Control of Corruption

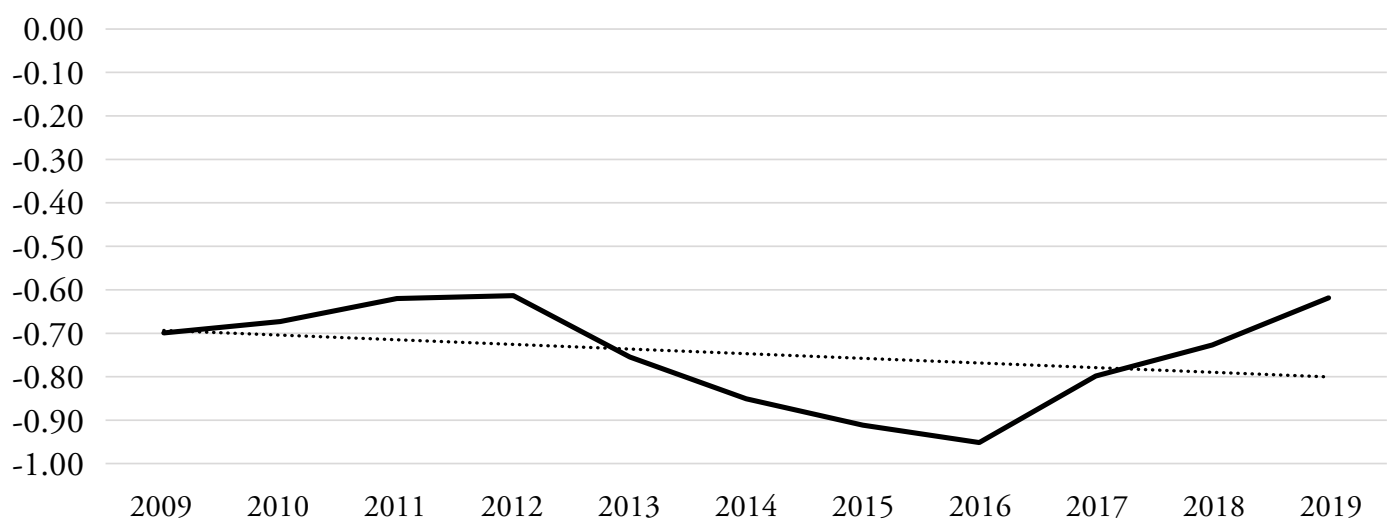

Source: World Bank, WGI.

Conversely, efficient policies in control of corruption would positively affect the other indicators. Nonetheless, the 2018 Transparency International corruption perception list and Freedom House's 2020 reports show small progress in the most recent past only, while the overall trend in those indexes, like the Democracy Index, demonstrate a declining long-term trend in democracy, corruption, political rights, and civil liberties. ${ }^{12}$ In fact, Moldova is involved in other international cooperation projects unrelated to the EU, but also concerning the control of corruption, ${ }^{13}$ which reinforces the depth of the problem in the country.

Figure 6. Rule of Law

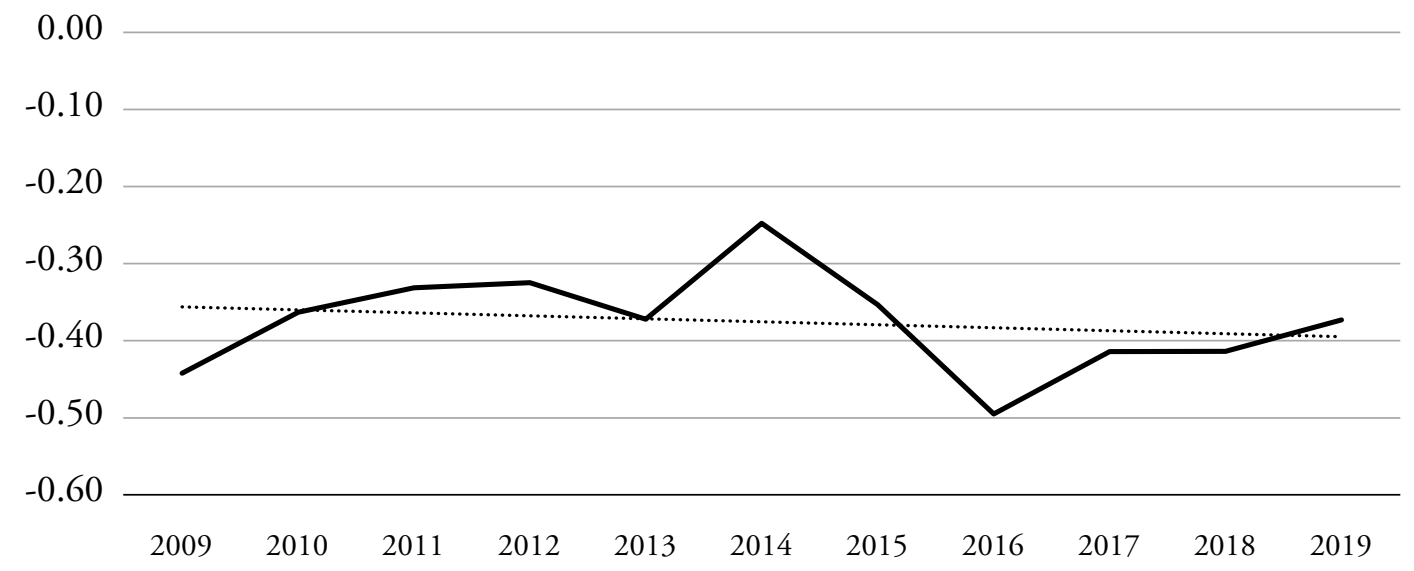

Source: World Bank, WGI.

There is a constant dispute of influences in Moldova, alternating periods of more significant Russian or European influence. Generally, the Russian influence during Dodon's government

\footnotetext{
12 See European Parliament (2020) and the Risk \& Compliance Portal.

${ }^{13}$ See, for example, the Action against Corruption in the Republic of Moldova, the project based on evaluation of GRECO. The Project is organised by the Council of Europe and the United States, aiming at supporting individual governments build justice and barriers against corruption.
} 
represents a setback in the changes in line with Western values that had been in place since the late 2000s. However, in the analysed period there is no constitutional and/or institutional rupture. Figure 6 shows the evolution of the Rule of Law indicator, which is very much in line with this lack of rupture.

\section{Perception and effectiveness of European policies and values in Moldova}

We consider that the increase of the good evaluation and positive perception of EU institutions, economy and politics are a way to legitimate the EU. Since its institutions, policies, politics, and values are perceived as positive or accepted as compatible with the national ones, we can consider a positive evaluation of EU influence and Europeanisation process and expect compliance and perception of legitimate Western influence in the country. Discourse on Europe is still dominated by states and European institutions, even more than domestic ones, or that of civil society representatives. Although we can expect important roles by national actors in developing the integration, Della Porta and Caiani (2009) highlight the impact of a greater participation of citizens in European public debates. The conviction that the laws and institutions represent the people and reflect justice promotes compliance and effectiveness of rules and norms. Thus, the analysis of perception data can reflect an evaluation, with a positive or negative vision and attitudes facing EU influence in countries and societies, creating an expectation of compliance.

\section{Figure 7. EU's image in Moldova}

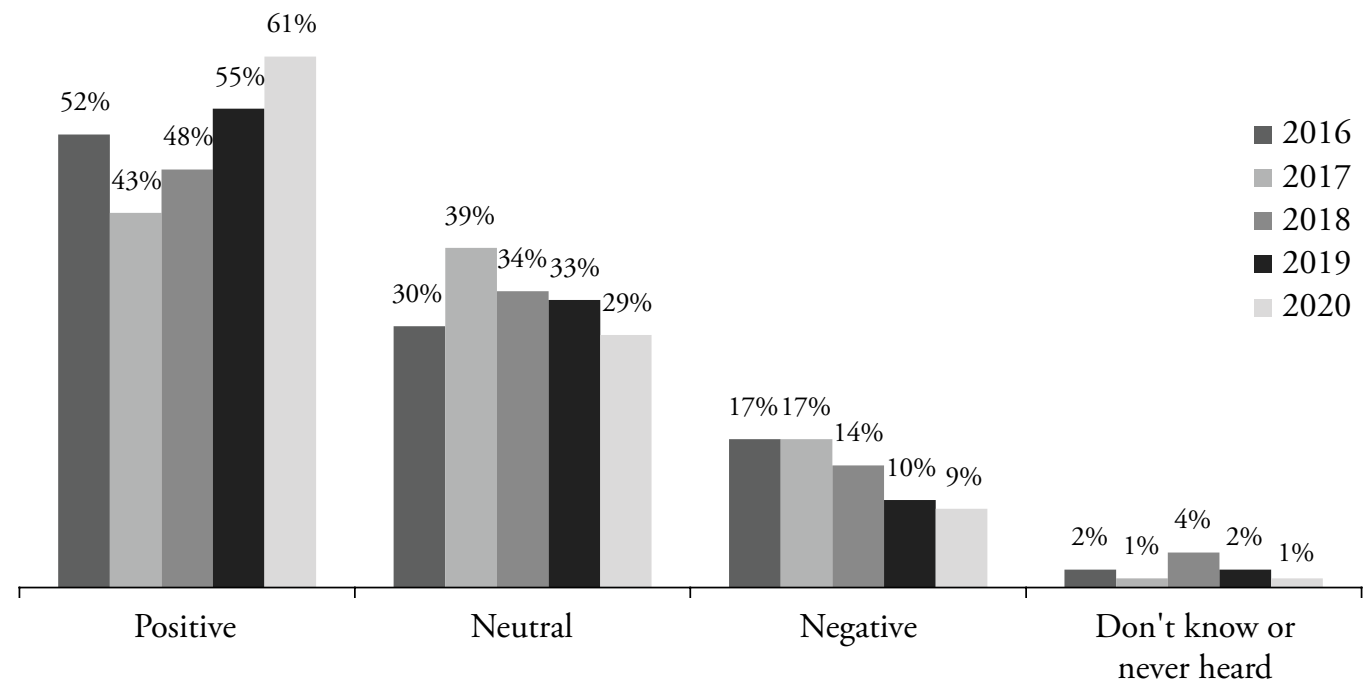

Source: Elaborated based on EU Neighbours east (2020).

According to data of the March 2020 survey $^{14}$, around half of Moldovan citizens have a positive image of the EU, representing an increase when compared to previous years' reports,

\footnotetext{
${ }^{14}$ The survey reflects data from the previous year. The authors felt that having the latest up-to-date information was of value in spite of the timeframe.
} 
as Figure 7 shows. However, significant differences were found within most socio-demographic groups, reflecting the country's heterogeneity. Of the $61 \%$ with a positive image of the EU, $88 \%$ are native Romanian speakers, $46 \%$ are young citizens, $12 \%$ classify as highly educated citizens and $47 \%$ reside in the centre of the country. Ethnic diversity is a significant feature of Moldova's population (Table 2), with different geopolitical orientations (Russia-led and Western-led), which in turn is reflected in the public perception of the EU.

Table 2. Ethnic structure of the population in Moldova - 2004 and 2014 censuses

\begin{tabular}{lcccccc}
\hline & \multicolumn{2}{c}{ Persons } & as \% to the total & \multicolumn{2}{c}{$\begin{array}{c}\text { as \%of total } \\
\text { population that } \\
\text { declared ethnicity }\end{array}$} \\
\cline { 2 - 7 } & $\mathbf{2 0 0 4}$ & $\mathbf{2 0 1 4}$ & $\mathbf{2 0 0 4}$ & $\mathbf{2 0 1 4}$ & $\mathbf{2 0 0 4}$ & $\mathbf{2 0 1 4}$ \\
\hline Total population & $\mathbf{3 , 3 8 3 , 3 3 2}$ & $\mathbf{2 , 8 0 4 , 8 0 1}$ & $\mathbf{1 0 0 . 0}$ & $\mathbf{1 0 0 . 0}$ & $\mathbf{x}$ & $\mathbf{x}$ \\
Population that declared etnicity including & $\mathbf{3 , 3 6 9 , 3 1 2}$ & $\mathbf{2 , 7 5 4 , 7 1 9}$ & $\mathbf{9 9 . 6}$ & $\mathbf{9 8 . 2}$ & $\mathbf{1 0 0 . 0}$ & $\mathbf{1 0 0 . 0}$ \\
Moldovans & $2,564,849$ & $2,068,058$ & 75.8 & 73.7 & 76.1 & 75.1 \\
Ukrainians & 282,406 & 181,035 & 8.4 & 6.5 & 8.4 & 6.6 \\
Russians & 201,218 & 111,726 & 5.9 & 4.0 & 6.0 & 4.1 \\
Gagauzs & 147,500 & 126,010 & 4.4 & 4.5 & 4.4 & 4.6 \\
Romanians & 73,276 & 192,800 & 2.2 & 6.9 & 2.2 & 7.0 \\
Bulgarians & 65,662 & 51,867 & 1.9 & 1.8 & 1.9 & 1.9 \\
Gypsies & 12,271 & 9,323 & 0.4 & 0.3 & 0.4 & 0.3 \\
Other ethnicities & 22,130 & 13,900 & 0.7 & 0.5 & 0.7 & 0.5 \\
Population that not declared ethnicity & 14,020 & 50,082 & 0.4 & 1.8 & x & x \\
\hline
\end{tabular}

Source: Elaborated with data from the National Bureau of Statistics of the Republic of Moldova (2014).

The AP and the AA are embedded in values. When it comes to values, the percentage of Moldovan citizens who have heard of the EU tend to associate all the values in the query with the EU, according to the survey's report, as follows: 
Figure 8. Values strongly (or very strongly) associated with the EU and three most important

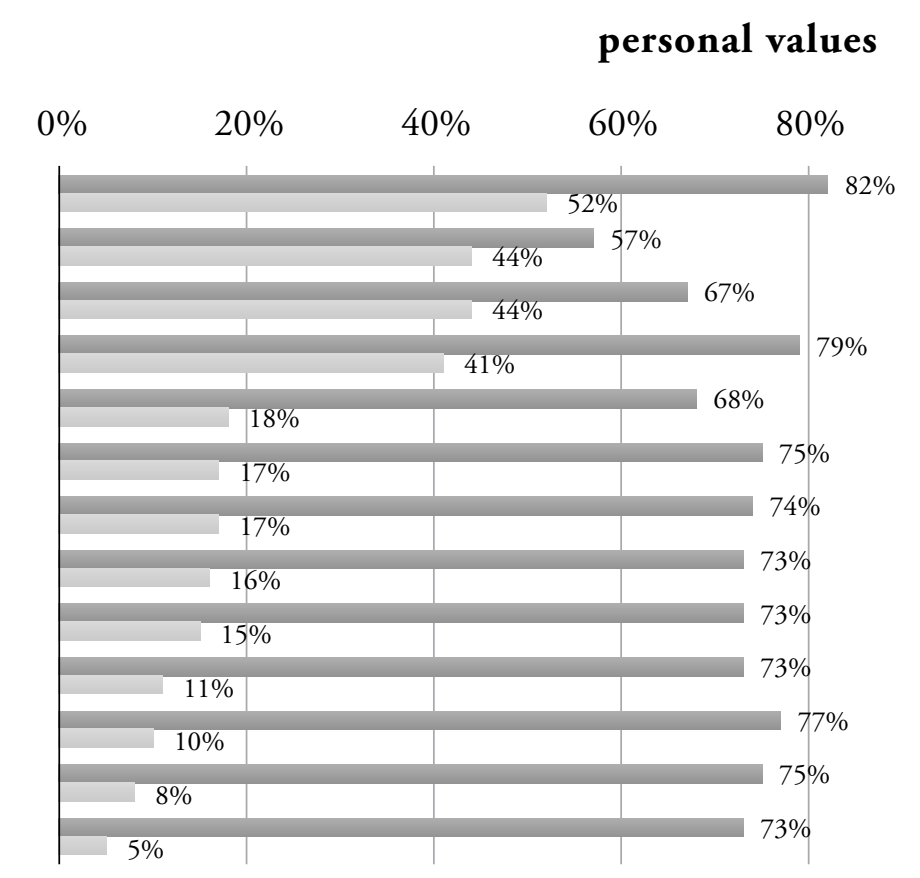

$100 \%$

Economic Prosperity

Absence of Corruption

Peace, Security and Stability

Human Rights

Honesty \& Transparency

Freedom of Speech

Democracy

Rule of Law

Equality and Social Justice

Individual Freedom

Freedom of Religion

Respect for other cultures

Freedom of the Media

- Values Strongly Associated with the EU

Most Important Personal Values

Source: Elaborated based on EU Neighbours east (2020).

The three most important personal values appointed by most of the respondents happen to be key topics in the Moldova-EU relations, strengthened over time with the AA and the DCFTA. Nonetheless, one of the most important personal values for $44 \%$ of the Moldovans is the absence of corruption, which is strongly associated with the EU for $57 \%$ of the interviewees.

Figure 9. Opinion on the statement: “The EU fosters the preservation of traditional values in

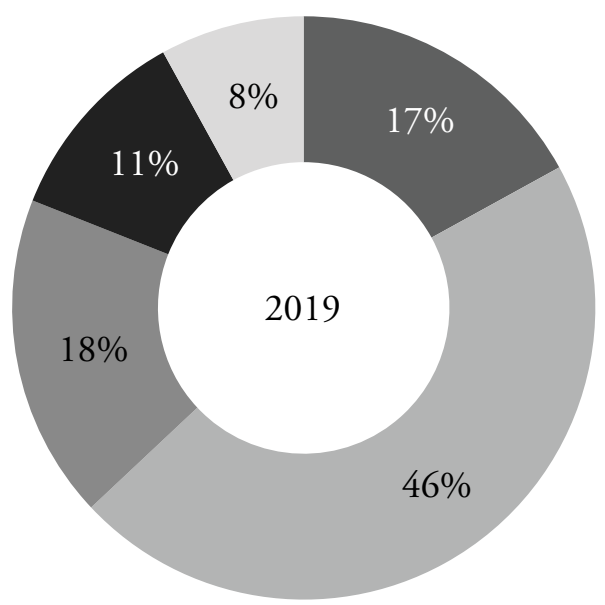
our society"

Source: Elaborated based on EU Neighbours east (2020).

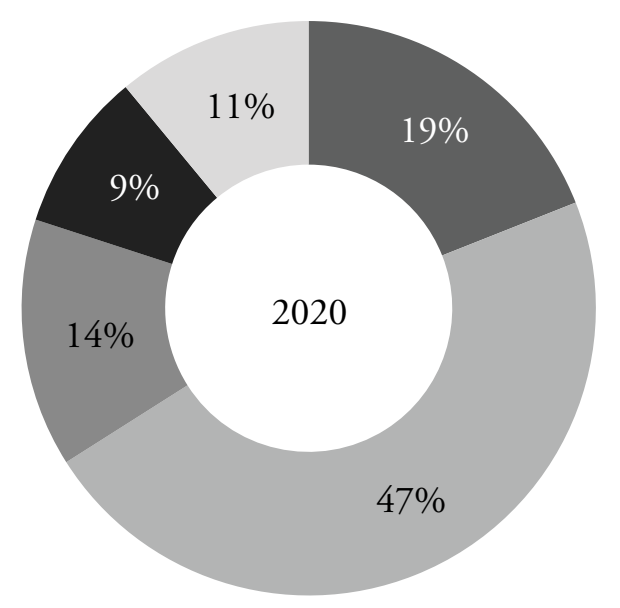

- Strongly

- Somewhat

- Not Really

- Not at all

Don't know 
While over half of the respondents agree the EU fosters traditional values in Moldovan society, most respondents seem to be unsatisfied with the way democracy works in Moldova (78\%). Nonetheless, there has been an improvement in the public satisfaction with democracy since 2016. Although it is not possible to establish a causal relation, the repercussions in society of the AA, which entered into force in 2016, may have been captured by the public opinion survey. Further improvements are expected in the years to come if the recently elected President Maia Sandu, the first female president of Moldova in office (since December 2020), delivers on her promises to resume the process of rapprochement with Europe and the commitment with the EU.

\section{Figure 10. Satisfaction with the way democracy works in Moldova}

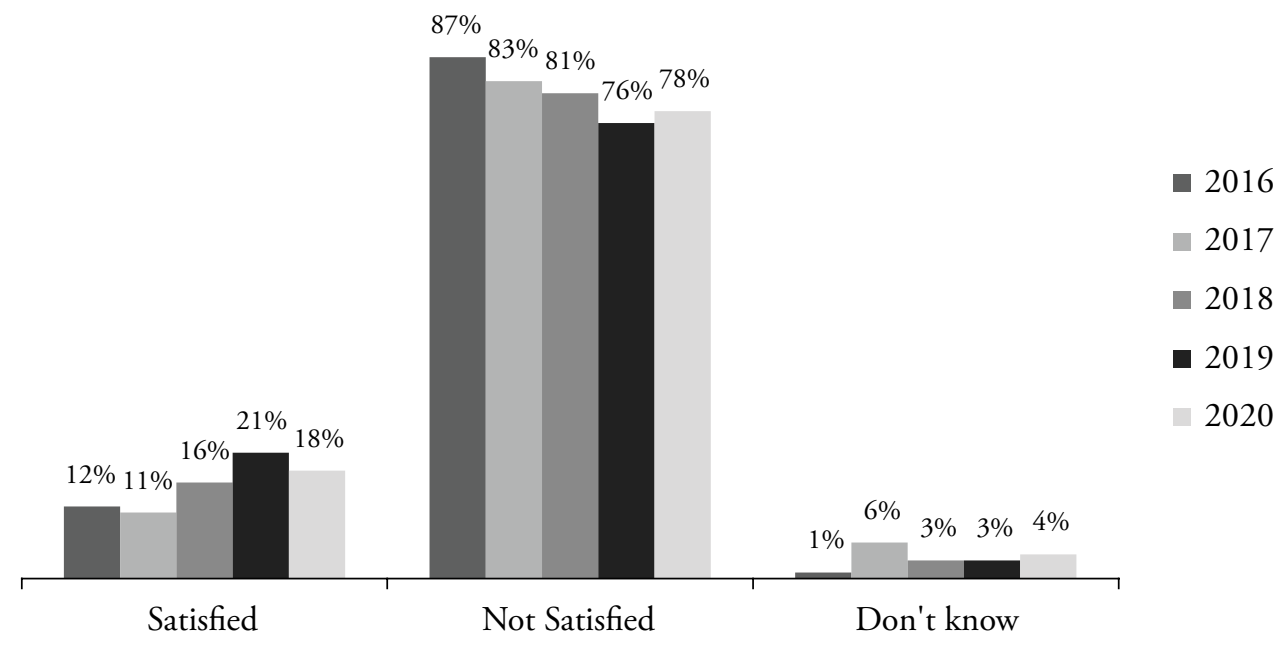

Source: Elaborated based on EU Neighbours east (2020).

The analysis of public opinion surveys prompts further connections related to identification with the EU. As Cram (2012) puts it, conscious or explicit identification with the EU may also emerge in the latent political community as the EU becomes a meaningful presence for its citizens. The deepening in EU-Moldova relations beyond simple cooperation has also reflected in the population's perception and identification with EU norms and values, as Figure 8 shows. The attachment and identification of the European public with the EU gives its policies, norms and institutions legitimacy and compliance - and that is particularly true for the case of the neighbouring countries.

Public opinion data already indicated education, high income, and an orientation towards liberal values alike had a strong correlation with support to EU membership among the former Soviet member-states at the enlargements since 2004 (Caplanova et al. 2004). Cram (2012) states that in order to appreciate functional benefits, individuals must experience those benefits. When it comes to Moldova, growing identification with the EU opposes identification with Russia, still very present in the country. In addition, for identification to occur they must relate those experiences and benefits to the level of authority concerned on the one hand and experience a 
process of "forgetfulness" on the other. Similarly, to what Renan (1990) highlights regarding building a collective national identity, it depends on forgetting the inconvenient past and replace it for a sense of belonging. A conception of national identity that does not oppose, but reaffirms and reassures itself on the opportunities promoted by EU values and norms.

The amounting of the EU's actions in Moldova and cooperation between member-states and the country have certainly increased the reaped experiences and benefits by the population, allowing an increase in its identification with Europe according to Cram's findings (2012).

\section{Conclusion}

Since 2003 the European Commission presented a new framework for relations with the Eastern and Southern neighbours. The involvement in the neighbour's stability matters from the EU's perspective. The EU has strong geopolitical interests in former Soviet countries in regard to economic development and consolidation of democracy in EU borders. The EU's influence in these countries can be seen as a win-win in the region. On the one hand, the EU spreads its norms, institutions, and compromises, thus expanding its liberal values, its rule of law model and exporting its agendas, such as the green transition; while on the other hand, the Eastern countries benefit from cooperation, economic development and investments, stability, democracy promotion and external relationships solidification initiatives.

According to Emerson et al. (2018), Europe's Eastern neighbours - Georgia, Moldova, and Ukraine - are countries facing a "choice" between external influencers. We could add that the other three EaP, Armenia, Azerbaijan and Belarus, which in different contexts present similar challenges, are divided between European and Russian influence. The struggle of political and economic transformation, from a post-Soviet to a European state, to become a European-style democracy, is represented by a kind of "European choice" (Emerson et al. 2018).

The EaP celebrated its $10^{\text {th }}$ anniversary in 2019 with a history of ups and downs. Much was achieved since the policy's launch in 2009, but also much has changed over the decade. Improvement in trade relations, the formalisation of wider partnerships with association and partnership agreements with some countries can be highlighted as outcomes of the EaP. As Korosteleva et al. (2020) highlight, differentiation and flexibility have permeated the EaP from the beginning, and still remain: the deepening in the six Eastern neighbours' relationship with the EU has evolved at different paces, given domestic and external conditions.

The ENP and its specific policy towards the Eastern neighbourhood have suffered various iterations ${ }^{15}$ to adapt to changes and keep on track of its goals. Like ones before it, the latest revision ${ }^{16}$ signals resilience and is to face the consequences of the recent global pandemic.

\footnotetext{
${ }^{15}$ Namely, 2008/2009, 2011, 2015 and most recently the 2019/2020 one.

${ }^{16}$ To be adopted in 2021 .
} 
Nonetheless, some preliminary conclusions can be drawn from the Europeanisation measured by the top-down aspects in the case of Moldova, when assessing the 2009-2019 period of EaP existence. When more direct benefits are involved, the pace of change increases. The EU's trade importance in Moldova grew after Russia's sanctions against Moldova in 2014 (Calus 2014). Back then, Russia was Moldova's main trade partner, but the AA/DCFTA changed that. Thus, top-down Europeanisation seems to occur without significant trouble in the economic cooperation and trade dimension.

Corruption is still a core issue in Moldova, and EU influence in matters related to it is more limited. In fact, it is the most relevant topic in Sandu's and pro-Europeans' platform. The WGI Control of Corruption indicator shows a deterioration trend from 2009 to 2019, indicating that despite the partnership with the EU and the AA, benefits have not been reaped yet. On the one hand, we consider the increases in transparency may generate more information about corruption and consequently a perception of increase in corruption; on the other, it is understandable to associate stagnation and, at a certain level, failure of the partnership to the extensive standstill period due to Dodon's Eurosceptic government (2016-2020). The year of 2016 represented a turn in the path the EU and Moldova were tracing together, which is confirmed by the data gathered on this research. Further investigation on what the 2016-2019 standstill might represent in the longer term, as well as the changes in the EaP to come into force, are welcomed in this research agenda.

Moldova faced recent domestic political events, including a constitutional crisis and a governmental crisis in the face of social divisions and views about the country's future. There is a clear dispute between society groups supporting different projects. Sandu, leader of the Party of Action and Solidarity (PAS), and the former President Dodon are representatives of the different views on the future of Moldova. Sandu was the Prime Minister from June to November 2019, and was elected President in December 2020. However, Dodon's Party and coalition partner have held the majority of seats in Parliament since then. Sandu has called an early parliamentary election for July $11^{\text {th }}, 2021$, when the PAS received $53.80 \%$ of votes, obtaining the majority in Moldova's Parliament. This victory has marked the end of an unfriendly political split between the Presidency and the Parliament. As a historic opponent of the country's pro-European agenda, Dodon has sought to strengthen himself in the shadow of Putin's image - a strong foreign political symbol in Moldova. He represents the share of Moldova's society that rejects the EU as the main external influence and a model to follow. The concrete outcome of the dispute between the defence of a pro-EU Moldova and a pro-Russia Moldova can also be measured from the results of ENP's success or failure if we consider the ENP a key foreign policy initiative and Europeanisation mechanism.

When it comes to democracy promotion, not coincidently human rights and rule of law were the most important values identified by the survey respondents. Deutsch et al. $(1957,85)$ refer to a "double process of habit-breaking", that is, the process through which citizens, exposed to the benefits available from a new level of governance, can start to break the habit of allegiance to the pre-existing political unit. Thus, we could argue that the more citizens are exposed to a 
EU-touched environment, the more the recognition that EU values, norms, and actions might coincide with the existing expectations. The expectations' fulfilment also promotes the legitimation of EU institutions. Results indicate that although the domestic institutional and political crisis is not yet overcome, the EaP and the ENP have silently and slowly reached partial goals of Europeanisation in Moldova.

\section{References}

Barbé, E. et al. "Drawing the Neighbours Closer...to What? Explaining Emerging Patterns of Policy Convergence between the EU and its Neighbours" Cooperation and Conflict 44, no.4 (2009): 378-399. doi: https://doi.org/10.1177/0010836709344423

Batt, J., Lynch, D., Missiroli, A., Ortega, M. and Triantaphyllou, D. "Partners and neighbours: a CFSP for a wider Europe.” Chaillot Paper, 64, 2003

Bobbio, Norberto. Teoria da Norma Jurídica. São Paulo: Edipro, 2012.

Börzel, T.A. "Pace-Setting, Foot-Dragging, and Fence-Sitting: Member State Responses to Europeanisation" Journal of Common Market Studies 40, no.2 (2002): 193-214. doi: https://doi.org/10.1111/1468-5965.00351

Calus, K. "Russian Sanctions Against Moldova. Minor effects, major potential. OSW Commentary" Centre for Eastern Studies 152, 2014. https://www.osw.waw.pl/en/ publikacje/osw-commentary/2014-11-06/russian-sanctions-against-moldova-minoreffects-major Accessed Oct. 12, 2021.

Caplanova, A, M. Orviska and J. Hudson. "Eastern European Attitudes to Integration with Western Europe” Journal of Common Market Studies 42, no.2 (2004): 271-288. doi: https://doi.org/10.1111/j.1468-5965.2004.00488.x

Cram, L. "Does the EU Need a Navel? Implicit and Explicit Identification with the European Union" Journal of Common Market Studies 50, no.1 (2012): 71-86. doi: https://doi.org/10.1111/j.1468-5965.2011.02207.x

Della Porta, D. and M. Caiani. Social Movements and Europeanisation. Oxford: Oxford University Press. 2009.

Deutsch, K. W., S. A. Burrel, R. A. Kann and M. Lee Jr. Political Community and the North Atlantic Area. New York: Greenwood, 1957.

Devyatkov, A. "Russian Policy Toward Transnistria” Problems of Post-Communism 59 no. 3 (2012): 53-62. doi: https://doi.org/10.2753/PPC1075-8216590305

Emerson, M., D. Cenusa, T. Kovziridze and V. Movchan. (ed.) "Struggle for Governance in Eastern Europe" Centre for European Policy Studies - CEPS, Brussells, 2018.

EU Neighbours east. "Association Agenda with the EU” (19-8-2017). https://eur-lex.europa.eu/legal-content/EN/TXT/?uri=CELEX\%3A22017D1489. Accessed Oct. 12, 2021. 
EU Neighbours east. “Annual Survey Report: Republic of Moldova” (16-06-2020). https://euneighbourseast.eu/news-and-stories/opinion-polls/opinion-survey-2020republic-of-moldova/. Accessed Oct. 12, 2021.

European Commission. "Joint Staff Working Document. Association Implementation Report on Moldova”(10-03-2017). https://eeas.europa.eu/sites/default/files/association_ implementation_report_on_the_republic_of_moldova_2017_03_10_final.pdf Accessed Oct. 12, 2021.

European Commission. "Joint Staff Working Document. Association Implementation Report on Moldova”(3-4-2018). https://eeas.europa.eu/sites/default/files/association_ implementation_report_on_moldova.pdf Accessed Oct. 12, 2021.

European Commission. "Joint Staff Working Document. Association Implementation Report on Moldova. Brussels" (12-9-2019). https://euneighbourseast.eu/news-and-stories/ publications/association-implementation-report-on-moldova/ Accessed Oct. 12, 2021.

European Commission. "Eastern Partnership implementation well on track - 1ast Eastern Partnership Foreign Ministers meeting” IP/09/1891 (8-12-2009). https://ec.europa.eu/ commission/presscorner/detail/en/IP_09_1891 Accessed Oct. 2021.

European Commission. "Joint Staff Working Document Implementation of the European Neighbourhood Policy in the Republic of Moldova." (25-05-2015). https://eur-lex.europa.eu/legal-content/EN/ALL/?uri=CELEX\%3A52015SC0069. Accessed Oct. 12, 2021.

European Parliament. "Report on the implementation of the EU Association Agreement with the Republic of Moldova” (28-9-2020). https://www.europarl.europa.eu/doceo/ document/A-9-2020-0166_EN.html\#title1 Accessed Oct. 12, 2021.

European Union External Action. "Stateman by Hight Representative/Vice-President Federica Mogherini following her meeting with the Prime Minister of Moldova, Chiril Gaburici” (26-02-2015). https://eeas.europa.eu/delegations/afghanistan/3221/ statement-by-high-representativevice-president-federica-mogherini-following-hermeeting-with-the-prime-minister-of-moldova-chiril-gaburici_en Accessed Oct. 12, 2021.

European Union External Action. "Shaping of a Common Security and Defence Policy" (08-07-2016). https://eeas.europa.eu/topics/common-security-and-defence-policycsdp/5388/shaping-of-a-common-security-and-defence-policy-_en Accessed Oct. 12, 2021.

Exadaktylos, T. "Methodological and Theoretical Challenges to the Study of the European Neighbourhood Policy" In: The Routledge Handbook on the European Neighbourhood Policy, edited by Schumacher, T., Marchetti, A. and Demmelhuber, T.. 93-103 London \& New York: Routledge, 2017.

Exadaktylos, T. and C. M. Radaelli. "Research Design in European Studies: The case of Europeanisation” Journal of Common Market Studies 47, no. 3 (2009): 507-530. doi: https://doi.org/10.1111/j.1468-5965.2009.00820.x 
Gawrich, A., I. Melnykovska, R. Schweickert. "Neighbourhood Europeanisation trough ENP. The Case of Ukraine" Working Paper KFG-The Transformative Power of Europe 3, August 2009. https://www.polsoz.fu-berlin.de/en/v/transformeurope/publications/ working_paper/wp/wp3/WP_03_August_Melnykovska_Gawrich_Schweickert.pdf Accessed Oct. 12, 2021.

Gstöhl, S. and E. Lannon. The Neighbours of the European Union's Neighbours. Diplomatic and Geopolitical Dimensions beyond the European Neighbourhood Policy. London \& New York: Routledge, 2014.

Hix, S. The Political System of the European Union. Basingstoke: Palgrave Macmillan. 2005. Kelley, J. "New Wine in Old Wineskins: promoting political reforms through the new "European Neighbourhood Policy" Journal of Common Market Studies 44, no.1 (2006): 29-55. doi: https://doi.org/10.1111/j.1468-5965.2006.00613.x

Knelangen, W. "A Neighbourhood of Freedom, Security and Justice?” In: European Neighbourhood Policy. Challenges for the EU-Policy Towards the New Neighbours, edited by Varwick, Johannes/Lang, Kai-Olaf, 78-101, Opladen, 2007.

Korosteleva, E. et al. “The Eastern Partnership 3.0: Change or Continuity?” Dahrendorf Forum. 2020. https://www.dahrendorf-forum.eu/the-eastern-partnership-3-0-change-orcontinuity/ Accessed Oct. 12, 2021.

Lavenex, S. and F. Schimmelfennig. "Concentric circles of flexible 'EUropean' integration: A typology of EU external governance relations" Comparative European Politics 9, no. 4-5 (2011):372-393. doi: https://doi.org/10.1057/cep.2011.7

McCauley, D. "Bottom-up Europeanisation Exposed: Social Movement Theory and NonState Actors in France" Journal of Common Market Studies 49, no.5 (2011):1019-42. doi: https://doi.org/10.1111/j.1468-5965.2010.02160.x

Montesano, F. S., T. van der Togt and W. Zweers. "The Europeanisation of Moldova: is the EU on the right track?" Clingendael Report. Netherlands: Netherlands Institute of International Relations. 2016. https://www.researchgate.net/publication/306018438_ The_Europeanisation_of_Moldova_is_the_EU_on_the_right_track Access Oct. 12, 2021.

Mukherjee, A. "Moldova - Improving Access to Justice: From Resources to Results. A Justice Sector Public Expenditure and Institutional Review" World Bank Group Report 2, no. 124516-MD. (19-09-2018). http://documents.worldbank.org/curated/ en/775621537510353149/Technical-Annexes Accessed Oct. 12, 2021.

OECD "Promoting Clean Urban Public Transportation and Green Investment in Moldova, Green Finance and Investment”, OECD Publishing: Paris. 2019.

Parmentier, F. "The European Neighbourhood Policy and Moldova. A resilient oligarchic system wedged between the EU and Russia" In: The Routledge Handbook on the European Neighbourhood Policy, edited by Schumacher, T., Marchetti, A. and Demmelhuber, T., 302-311, London \& New York: Routledge, 2017. 
Popescu, N. EU Foreign Policy and Post-Soviet Conflicts. Stealth intervention. London \& New York: Routledge, 2011.

Popescu, N. "The EU in Moldova -Settling conflicts in the neighbourhood" The EU Institute for Security Studies. Occasional Paper 60. October 2005.

Radaelli, C. "Whither Europeanisation. Concept stretching and substantive change" European Integration online Papers (EIoP) 4, 2000.

Spruds, A. "Introdutory Remarks." In Dilemmas of Europeanisation: Political Choices and Economic Transformations in the Eastern Partnership Countries, edited by Austers, A., I. Bruge, A. Spruds., 9-12. Letónia: Latvian Institute of International Affairs and Friedrich-Ebert-Stiftung, 2016.

Wolczuk, K. "The Development of an Institutional Framework for the Implementation of the Association Agreements in Georgia, Moldova and Ukraine: a comparative perspective" European Parliament. Directorate-General for External Policies (21-09-2018), https://op.europa.eu/en/publication-detail/-/publication/2a399048-bfc811e8-99ee-01aa75ed71a1/language-en Accessed Oct. 12, 2021.

World Bank. "Worldwide Governance Indicators." (27-05-2020), https://info.worldbank. org/governance/wgi/\#home. Accessed Oct. 12, 2021. 